\title{
Notas Sobre o Conservadorismo: elementos para a definição de um conceito
}

Helga Gahyva'

\section{Resumo}

O presente artigo inspira-se nos usos pouco precisos do conceito de conservadorismo na contemporaneidade. Quais características, afinal, definem o pertencimento a essa corrente de pensamento? Para responder à questão, optou-se pela construção de uma visão ideal típica da filosofia conservadora por meio da qual foi possível destacar suas principais premissas. Para tanto, privilegiou-se a análise do conceito em movimento, ou seja, em diálogo com alguns de seus mais destacados expoentes.

Palavras-chave: Pensamento conservador. Revolução Francesa. Igualdade. Liberdade. Mudança social.

\section{Introdução}

Nas sociedades contemporâneas, crescentemente adaptadas ao veloz fluxo de informaçóes, opiniôes e debates, os litigantes náo raramente adotam o adjetivo conservador no intuito de desqualificar as alegaçôes de seus oponentes. Nesse sentido, ser conservador parece equivaler, de modo simplório, ao ponto de vista contrário àquele que se deseja defender. Trata-se de uso que esvazia o sentido do conceito, tornando-o espécie de ofensa cujo conteúdo se adapta às mais diversas perspectivas.

Ainda no registro caro ao senso comum, o termo é usado em acepçáo pouco mais restrita. Conservador seria epíteto próprio a espíritos avessos a mudanças que, não satisfeitos em esposar formas de existência cristalizadas pelo tempo, exigiriam que a totalidade dos membros de uma determinada sociedade se dobrassem às suas verdades absolutas. Segundo esse ponto de

Doutora em Sociologia pelo luperj/Ucam. Professora adjunta do Departamento de Sociologia do Instituto de Filosofia e Ciências Sociais da Universidade Federal do Rio de Janeiro (IFCS/UFRJ) e do Programa de Pós-Graduação em Sociologia e Antropologia (IFCS/UFRJ).E-mail: helga.gahyva@gmail.com 
vista, desmanchar-se-iam no ar as distinçóes entre conservadores e autoritários - ambos compreendidos como inimigos históricos do pluralismo societário.

Esses usos pouco precisos e constantemente histriônicos justificam a discussão levada a cabo no presente artigo. Trata-se de uma tentativa de regatar os fundamentos de um conceito que, a despeito de suas variaçóes internas, compóem um panorama de premissas relativamente coerentes e com feição específica.

Para cumprir a tarefa, investigo e discuto certas características que, articuladas conjuntamente ${ }^{2}$, possibilitam a construçáo de uma imagem ideal típica do pensamento conservador (WEBER, 1989, p. 105-123). Quais são as principais preocupações histórico-metodológicas dessa perspectiva que, junto ao liberalismo e ao socialismo, constituem uma das três grandes ideologias modernas? (NISBET, 1987, p. 9). Neste movimento, procuro estabelecer um diálogo entre as linhas mestras do conservadorismo e alguns de seus mais destacados expoentes ${ }^{3}$, de modo a perceber como elas foram por eles incorporadas e reinterpretadas.

Este artigo não possui a incauta pretensão de esgotar a caracterização do pensamento conservador. Limites de ordem variada conduzem a recortes que, na qualidade de escolhas, implicam renúncias. A análise incide sobre a gênese e o desenvolvimento da ideologia conservadora no período compreendido entre os momentos subsequentes à Revolução Francesa e meados do pósPrimeira Guerra Mundial, abrangendo, em sua maioria, autores cuja visão de mundo foi gestada durante o "longo século XIX". Assumo a hipótese de que tal digressáo é fundamental ao esforço de desanuviar o uso pouco criterioso do conceito de conservadorismo na atualidade. Não se trata, portanto, de uma investigação sobre seus desdobramentos contemporâneos ou sobre suas formas específicas de circulação no Novo Mundo - tarefas que se pretende

2 A dimensão de conjunto é especialmente importante para a caracterização do conservadorismo, pois, se consideradas isoladamente, boa parte dos traços discutidos mais adiante são compartilhados pelo liberalismo $e$, algumas vezes, até mesmo pelo socialismo.

3 A seleção de autores que ocupa a sessão seguinte inspirou-se na bibliografia sobre pensamento conservador, indicada ao fim do artigo. Ela não é, contudo, integralmente consensual. Nisbet (1987, p. 15-16), por exemplo, não titubeia ao filiar Tocqueville à linhagem burkeana; Sternhell, em contraste, recusa a associação entre ambos, vinculando Burke a uma tradição que denomina "liberalismo bloqueado" (STERNHEL, 2010, p. 60-6I), distante dos "liberais conservadores autênticos" à Tocqueville (STERNHEL, 20I0, p. 36). 
doravante desenvolver, mas que, reitero, não será bem-sucedida sem o recurso à discussão a seguir.

\section{O conservadorismo em movimento}

Para a investigaçáo do conservadorismo, recorro a um conjunto de estudos que, não obstante sua heterogeneidade interna, estabelece os traços gerais que o definem. Variam recortes, preocupaçóes e nomenclaturas, mas permanece a descriçáo do pensamento conservador como uma ideologia cuja origem se localiza no movimento de reaçáo à Revolução Francesa e à sua Declaração de Direitos. Nesta chave, a referência obrigatória é Edmund Burke e suas Reflexóes sobre a Revolução em França (1790), espécie de Bíblia do pensamento conservador (NISBET, 1987) na qual são expostos os temas essenciais que moldam essa "estrutura mental objetiva" (MANNHEIM, 1982, p. 109).

O opúsculo do publicista irlandês nasce em reação à convergência estabelecida por Richard Price entre as revoluçóes americana e francesa. Em ambos os casos, o pastor dissidente reconhece batalhas da liberdade contra poderes opressores. O contra-argumento de Burke tem função dupla: de um lado, revelar a impropriedade da argumentaçáo de Price; afinal, em sua opiniáo, os colonos americanos lutavam pela preservaçáo de seus hábitos e costumes em face de uma potência estrangeira, enquanto o movimento revolucionário francês implicava o oposto - uma luta pelo poder absoluto liderada por "homens de letras" (BURKE, 1997, p. 108) cujo raciocínio geométrico os levava, arbitrariamente, a violentar os moeurs caros à velha França. De outro, Burke (1997) teme a reverberaçáo dos ecos revolucionários além-Mancha (p. 52); mesmo reconhecendo que "graças à nossa obstinada resistência à inovaçáo [...] não fomos convertidos por Rousseau” (p. 107), ele faz questáo de lembrar que "a França sempre influenciou, ora mais, ora menos, os costumes na Inglaterra" (p. 103), justificando a sua preocupaçáo com a permanência da situaçáo de paz entre os insulares.

As Reflexóes apresentam os temas centrais que compóe a agenda conservadora dos últimos dois séculos (NISBET, 1987). A despeito das necessárias adaptaçóes de um corpo de ideias ancorado na noção de circunstância e, por isso, sempre referido a conjunturas específicas (BURKE, 1997; BOBBIO; MATTEUCCI; PASQUINO, 1991), é possível discernir 
pressupostos fundamentais que lhe conferem inteligibilidade. Destaca-se, entre eles, uma nostálgica reavaliação da experiência feudal e de suas estruturas históricas correspondentes. Deriva, daí, a premissa conservadora quanto ao direito de sobrevivência das estruturas intermediárias da nação ${ }^{4}$.

Em reação à pauta centralizadora e individualizante característica da formaçáo dos Estados modernos, o pensamento conservador empreende movimento de valorização das tradiçóes, tal como se percebe na crescente fascinação pela Idade Média e pelo elogio ao espírito de regionalismo que são observados na Alemanha de meados do século XXIII (NISBET, 1987, p. 66) ${ }^{5}$. Se a crítica à concentração de poderes nas capitais nacionais tornase um topos do conservadorismo, cumpre elogiar a solução além-Reno, cuja unidade política comparativamente tardia fora capaz de preservar a vida provincial. O contraste tem vida longa, reaparecendo, por exemplo, no lamento de Ernest Renan (1872, p. 31) pela impossibilidade, em França, cuja capital era o "centro da utopia republicana", do exercício daquele liberalismo moderado característico dos beligerantes vitoriosos em Sedan. Pouco mais de meio século depois, Gustave Le Bon (1927, p. 213) reforça a comparação: "na França há somente um centro intelectual: Paris; a Alemanha tem vários". Em comum a esses personagens, a convicçáo segundo a qual "a centralização provoca apoplexia no centro e anemia nas extremidades” (NISBET, 1987, p. 106).

Aos olhos da primeira geração conservadora (STERNHELL, 2010, p. 40), o Antigo Regime é, sem dúvida, preferível à igualdade de condiçóes, mas daí não deriva sua superioridade inconteste. Ocorre que, para os contemporâneos à Revolução Francesa, a crítica à monarquia absoluta revela sua face contraproducente, e os ataques ao Antigo Regime tornam-se, praticamente, monopólio dos revolucionários. Parafraseando suposto dito de certo príncipe, para esses primeiros conservadores era monarquia ou morte. Fosse por razóes históricas (BURKE, 1997) ou teológicas (MAISTRE, 2010), a defesa da velha ordem confundia-se com o combate à igualdade legal.

4 Na narrativa burkeana, o tema da valorização do passado feudal pode ser ilustrado por meio de seu lamento pelo declínio da idade do cavalheirismo, sucedida por "aquela dos sofistas, dos economistas, dos calculadores" (BURKE, 1997, p. 100).

5 "Eles não exibem nostalgia pelo passado imediato, mas por uma história altamente seletiva, e mais frequentemente, ao menos até o início do século XX, pela cultura orgânica da Idade Média cavalheiresca e cristã tal como eles a veem" (STERNHELL, 20I0, p. 62). 
No primeiro volume de $A$ democracia na América (1835), Alexis de Tocqueville (1998, p. 11) transforma a igualdade em fato providencial $^{6}$, decretando a derrota definitiva do Antigo Regime. O reconhecimento da irreversibilidade do estado social igualitário repóe o tema da crítica à potência real na agenda conservadora, explicitando sua admiração pela ordem social medieval, aquela corroída pelo movimento centralizador parteiro do moderno Estado-nação.

Nessa interpretação, ao Antigo Regime é atribuída a responsabilidade pela Revoluçáo. A via francesa de acesso à modernidade igualitária fora produto do processo de centralizaçáo administrativa inaugurado pela monarquia absoluta. A progressiva ampliação do raio de açáo do poder público, destruindo o que restava das estruturas medievais de autogoverno, "[...] atraiu e engoliu em sua unidade todas as parcelas de autoridade e influência antes disseminadas numa porção de poderes secundários [...] espalhados em todo o corpo social” (TOCQUEVILLE, 1998, p. 56). Esvaziando os corpos intermediários, simultaneamente promotores da diversidade local e garantidores das liberdades, o Estado assume o papel de agente da uniformidade, ou seja, de promotor da igualdade par excellence.

Ver-se-á mais adiante que o crescente nivelamento promovido pelo poder central é entendido, na perspectiva conservadora, como antagônico ao exercício da liberdade. Por ora, cumpre acentuar o elo que ela estabelece entre liberdade e diferenciação - sobretudo social, mas também regional. Daí sua incompatibilidade histórica com a igualdade: em sua maior parte, as formas de igualdade "[...] parecem aos conservadores ameaças às liberdades tanto do indivíduo como do grupo, liberdades que são inseparáveis da diferenciação inata, da variedade e das diversas oportunidades que são tantas vezes o alvo do igualador" (NISBET, 1987, p. 90-91) ${ }^{7}$.

Trata-se da reconstrução da época medieval enquanto lócus privilegiado da liberdade, da heterogeneidade e da descentralização, progressivamente submetidas à potência real, que as substitui pela igualdade, pela homogeneidade

6 Para discussão sobre o recurso de Tocqueville ao argumento providencial, ver: Jasmin, 1997, p. 184-220.

7 No caso de Burke, até mesmo a igualdade legal: em sua concepção, a divisão em ordens representa "forte barreira contra os excessos do despotismo" (BURKE, 1997, p. 178). 
e pela centralização (GAHYVA, 2012, p. 169-171). Constitui-se, assim, tanto como lamento pelo enfraquecimento da nobreza provincial (RENAN, 1872) quanto como desprezo pela sociedade de corte (ELIAS, 2001): "Versalhes entenda-se aquele Versalhes dos trejeitos - não é aristocracia, é o oposto: é a morte e a putrefação de uma aristocracia magnífica" (ORTEGA Y GASSET, 2007, p. 50).

Náo seria exagero afirmar que, na perspectiva conservadora, o Antigo Regime produz os germes que o destruirão. Esta é uma das principais liçôes extraídas da narrativa de Tocqueville: a centralização e o socialismo são produtos do mesmo solo (TOCQUEVILLE, 1991, p. 149). Ou seja, a monarquia absoluta, a Revolução e o desenvolvimento do socialismo são momentos diversos da mesma cadeia igualitária que conduz as sociedades modernas ao nivelamento. "Sob nomes novos, nós continuamos, na realidade, o Antigo Regime", afirma Le bon (1927, p. 212), reiterando, no Entreguerras, o argumento tocquevilliano. Trata-se do reconhecimento de uma mentalidade secular que se materializa na substituiçáo da iniciativa individual pela autoridade do Estado (LE BON, 1927, p. 212).

Se o poder central legisla universalmente, a expansão de seus direitos leva de roldão os privilégios herdados consagrados pelos costumes que, segundo o conservadorismo, constituem a própria esfera de exercício da liberdade. Em outros termos, a liberdade, oposta ao universalismo, confunde-se com o pluralismo (ORTEGA Y GASSET, 2007, p. 16). Ela não existe em abstrato, apenas referida aos mours de cada grupamento humano específico. Ou seja, "não se pode estabelecer o reinado da liberdade sem o dos costumes" (TOCQUEVILLE, 1987, p. 17).

Reitera-se, aqui, pressuposto básico da interpretaçáo conservadora: o apelo ao concreto (MANNHEIM, 1982). Referida às circunstâncias, ela censura o pensamento revolucionário por "fechar os olhos ao homem real" (TAINE, 1986, p.160). O "homem em geral", tributário de direitos universais, constitui ilusão própria àqueles que ambicionam encapsular a diversidade histórica em uma equivocada concepção aritmética da vida social, conforme cita Maistre (2010, p. 180): "Já vi, na minha vida, Franceses, Italianos, Russos etc.; sei mesmo, graças a Montesquieu, que se pode ser Persa; mas, quanto ao homem, declaro nunca o ter encontrado na minha vida; se existe, não tenho conhecimento" . 
A famosa condenação do publicista savoiano à concepção universalista de homem, presente em Consideraçôes sobre a França (1797), é bastante reveladora da aversão conservadora a quaisquer perspectivas hipotético-dedutivas. Subjaz a ela a adesão à metáfora da tábula rasa, cliché contrarrevolucionário (STERNHELL, 2010) sugerido por Burke (1997) em sua crítica ao quixotismo daqueles homens de letras que ambicionaram refundar a sociedade francesa recorrendo aos preceitos universalistas da razão - e que será retomado, nos anos 1850, por Tocqueville.

No já citado $O$ Antigo Regime e a Revolução (1856), o aristocrata normando mostra como, a partir do século XVIII, a crescente centralização administrativa tornou os franceses estranhos à coisa pública, criando um contexto no qual o exíguo exercício da liberdade política os teria levado a desprezar "os costumes complicados e tradicionais que regem a sociedade do seu tempo", substituindo-os por "regras simples e elementares extraídas da razão e da lei natural” (TOCQUEVILLE, 1987, p. 135).

O tema do repúdio às abstraçóes ecoa tanto no conservadorismo de Hippolyte Taine quanto no de Le Bon. O primeiro, analisando a ruína do Antigo Regime em Les origines da la France contemporaine (1875), atribui papel fundamental ao torpor produzido pela inédita autoridade conferida à razão na crescente convicção dos franceses quanto à possibilidade de "modelar toda a vida humana a partir de um tipopreconcebido" (TAINE, 1986, p. 154). Le bon (1922, p. 113), por sua vez, recorre constantemente a Tocqueville - e ao próprio Taine - em seu estudo sobre a Revolução Francesa (1912), atentando para a ação daqueles "[...] escritores fatalistas [...] imbuídos de um ideal novo contra as leis econômicas, sociais e políticas que conduzem os homens e que eles não compreendiam". Por trás dessas críticas, outra sugestáo burkeana que constitui mais um topos do pensamento conservador, e que pode ser entendida como uma concepção tridimensional de tempo.

Como mostra Koselleck (2006), a emergência do tempo histórico moderno supóe o divórcio entre espaço de experiência e horizonte de expectativa ou, em outros termos, a falência da perspectiva histórica exemplarista, expressa na máxima ciceroniana historia magistra vitae. Nesta forma cíclica de compreensão do tempo, "[...] a estrutura temporal da história passada delimitava um espaço contínuo no qual acontecia toda a experimentação possível" (KOSELLECK, 
2006, p. 43). Ora, o caráter inédito das revoluçóes do final do século XVIII - e da francesa, em particular - veda o recurso ao cabedal de exemplos pretéritos, possibilitando a compreensáo da modernidade como tempo singularmente distinto tanto do passado quanto do futuro. Trata-se da formação de uma concepção de história linear, articulada em torno da noção de progresso, na qual o futuro ultrapassa o espaço das experiências tradicionais (KOSELLECK, 2006, p. 320). Ou seja, nesta concepção de história como singular coletivo, na qual as histórias são temporalizadas no processo único da história universal, os exemplos provenientes do passado perdem seu caráter pedagógico.

Contra a nova forma progressista de experimentar o tempo bradam as Reflexôes de Burke. Em reação à narrativa revolucionária, desejosa da construção de um futuro emancipado dos conselhos do passado, ele ambiciona limitar o tempo histórico ao espaço de experiência: "A história é um grande livro aberto para o nosso aprendizado, pois os erros do passado, os males que fizeram sofrer o ser humano são grandes fontes de liçóes de sabedoria para o futuro" (BURKE, 1997, p. 46).

Aqui, julga Burke, o equívoco dos racionalistas é duplo: por um lado, entendem o presente como início do futuro, e náo, como seria correto, como estágio mais avançado do passado; por outro, não percebem as amarras que constrangem esse mesmo presente - ele não é livre, pois representa uma associação entre os vivos, os mortos e aqueles que vão nascer. Forma-se, desse modo, uma hipótese basilar da filosofia conservadora da história: somente podemos saber onde estamos ou aonde vamos se soubermos onde estivemos (NISBET, 1987).

O conservadorismo, reativamente, despreza a concepção linear de história, privilegiando a noção de coexistência em detrimento da de sucessão (MANNHEIM, 1982, p. 128). Assim, o futuro deixa de ser abstrato por princípio, tornando-se apenas a princípio abstrato; ele adquire concretude quando se permite guiar pelas experiências acumuladas.

Maistre, leitor de Burke, retoma o tema da defesa da história como memória dos povos. Reside nesta convicção seu repúdio à adesão republicana sugerida por Benjamin Constant (1988), em 1796, em De la force Du governement actuel de la France et de la necessite de syrallyer. Sua justificativa para o retorno da monarquia fundamenta-se no paradigma ciceroniano, pois 
ele aponta para a incompatibilidade entre uma grande nação livre e o governo republicano recorrendo aos exemplos pregressos (MAISTRE, 2010, p. 142).

A pregnância histórica da concepção tridimensional do tempo pode ser ilustrada pela forma como o tema é retomado, já na primeira metade do século XX, por Ortega y Gasset. Em A história como sistema (1941), ele atribui à memória, e não à inteligência, o traço singular da espécie humana (ORTEGA Y GASSET, 1982, p. 49). O escritor madrilenho alça o direito à continuidade ao estatuto de direito fundamental do homem. Assim, na sua concepçáo, percebe-se que não é a expectativa, mas a experiência o elemento definidor da humanidade. Essa perspectiva foi radicalizada em $A$ rebelião das massas (1930), obra na qual Ortega y Gasset nos assegura que "[...] romper a continuidade do passado, querer começar de novo, é aspirar a descer e plagiar o orangotango" (ORTEGA Y GASSET, 2007, p. 34). Reencontra-se, aqui mais de um século depois de Burke - o tema da tábula rasa: o pecado original da Revolução Francesa fora a violação daquele direito básico à continuidade, pois a miopia revolucionária não perceberia que "[...] a configuração histórica existente em uma dada época não pode ser construída artificialmente, mas cresce como uma planta, a partir da semente" (MANNHEIM, [s. d.], p. 258).

Se os revolucionários reivindicam a refundação da sociedade a partir da noção de direito natural, Burke opera uma reversáo sistemática da ideia de natureza que fará escola no pensamento conservador. Para ele, natural não é o que vale para todos os homens, ou aquilo que pertence essencialmente à natureza humana - isto é, o que se refere ao homem considerado anteriormente a todos os vínculos sociais. Natural, ao contrário, corresponde ao resultado de longo desenvolvimento histórico. Para Burke, a natureza equivale à história. Por isso, o bom estadista não é o criador, mas o aperfeiçoador, isto é, aquele que busca aliar conservação e adaptação, reconhecendo a pouca eficácia da razáo individual em face do longo acúmulo das experiências das geraçóes precedentes. $\mathrm{O}$ estadista sagaz, enfim, valoriza o espaço de experiência em detrimento do horizonte de expectativa, apoiando seu governo na noção de circunstância e em seu correlato programa de valorizaçáo do preconceito.

Os homens de letras, em oposição, "[...] pensa[m] pouco, ou quase nada, naquilo que foi feito antes de sua época e vive $[m]$ apenas em funçáo de novas descobertas" (BURKE, 1997, p. 108). Embriagado por um "sistema 
quimérico de deliberação e de construção política pelos raciocínios anteriores" (MAISTRE, 2010, p. 196), o pensamento revolucionário estabelece o preconceito contra o preconceito (TAINE, 1986), desprezando essa forma privilegiada de conhecimento prático, anterior ao intelecto, que resume, na mente individual, a autoridade e a sabedoria contidas na tradição.

Na filosofia conservadora, a noção de preconceito ergue-se contrariamente à de tábula rasa: se esta encontra suas condiçóes de possibilidade no recurso a uma concepção universalista de razão, ao outro, por sua vez, subjaz a percepçáo segundo a qual há certo modo natural de funcionamento dos assuntos humanos que apenas a história é capaz de revelar. A diferença pode ser ilustrada por meio do contraste, caro ao pensamento conservador, entre as revoluçóes francesa e inglesa.

Em seu estudo sobre o desenvolvimento do movimento de oposição aos ideais ilustrados, Sternhell lhe atribui como ponto-chave certa interpretaçáo dos momentos finais do século XVII inglês na qual foi necessário “[...] a todo custo que o ano de 1689 náo constituísse o início de uma nova era, mas uma simples restauração das antigas liberdades inglesas" (STERNHELL, 2010, p. 25) $)^{8}$. Ele revela como, em desacordo com a versáo lockeana, Burke constrói uma interpretação na qual a Revolução Gloriosa converte-se em "revolução evitada” (STERNHELL, 2010, p. 322).

Nesse movimento de louvaçáo a um povo, conforme explicita Le Bon (1922), "de adaptação progressiva" (p. 8) que não se permitiu "[...] destruir a herança ancestral, no intuito de refazer uma sociedade nova em nome da razão" (p. 43). Taine dá prosseguimento à sugestão burkeana, julgando os dois Tratados sobre o Governo Civil uma codificação das liberdades inglesas e não uma teoria dos direitos naturais (STERNHELL, 2010).

Assim, tais liberdades seriam menos novidade derivada da revolução do que ressurreição de suposta antiga constituição. Esta particular interpretação

8 De modo semelhante, "[...] os críticos das Luzes fizeram de tudo para dar crédito à ideia segundo a qual a rebelião das colônias inglesas da América não era de modo algum uma revolta contra o Antigo Regime, e menos ainda uma revolta da razão soberana contra a história" (STERNHELL, 2010, p. 26). Para Friedrich Von Gentz, tradutor de Burke para o idioma alemão, por exemplo, a Declaração de Independência era espécie de cobertura ideológica que os colonos necessitavam para dar à secessão dimensões épicas, mas eles não tinham intenção de opor direitos do homem aos direitos específicos das comunidades históricas (STERNHELL, 2010, p. 27). 
da história inglesa fundamenta outro topos do conservadorismo: o elogio à Inglaterra, espelho invertido da equivocada França revolucionária.

Se, do outro lado da Mancha, no emblemático ano de 1789, Sieyès (1988, p. 147-148) cria ser bem-sucedido em seu objetivo de submeter os preconceitos aos princípios da verdade (1988, p. 147-148) ${ }^{9}$, o caráter nacional dos insulares trazia, segundo Burke (1997, p. 108), a marca de seus antepassados, tornando-os resistentes às inovaçóes. Majoritariamente imunes à voga ilustrada, os ingleses reconheceriam a inoperância de uma constituição fabricada pela reflexão, optando por um sistema político que, em constante diálogo com a tradição, não se deixaria perturbar pela lógica abstrata. Os franceses, por seu turno, iludem-se ao crer que um arranjo constitucional possa ser obra de aritmética (BURKE, 1997, p. 186).

Por trás da crítica aos revolucionários, Burke mostra-se convicto quanto à superioridade do direito consuetudinário. Maistre segue a mesma trilha, denunciando o recurso à lei escrita como mecanismo de reconstrução das sociedades. Trata-se de perceber o texto legislativo como espécie de constituição natural da nação (MAISTRE, 2010, p. 172).

Nesse sentido, a cada povo corresponde uma constituição particular. A recomendaçáo aqui é clara: deve-se evitar o equívoco das constituiçóes francesas, que ambicionam se dirigir à natureza humana, pois "[...] uma constituição que é feita para todas as nações não é feita para nenhuma” (MAISTRE, 2010, p. 180).

A sólida afeição conservadora pela constituição inglesa nutre-se da convicção segundo a qual, referida às circunstâncias nacionais específicas, ela soube transformar-se paulatinamente, sem que mudanças implicassem rompimento com preconceitos imemoriais. "E são precisamente estas novas coisas introduzidas com arte neste velho corpo que o reanimaram sem o risco de dissolvê-lo, dando-lhe um novo vigor sem tirar-lhe $[$ sic $]$ as formas antigas" (TOCQUEVILLE, 1987, p. 62).

O elogio à via transformista inglesa (VIANNA, 1987) como forma própria de ingresso à modernidade é fundamental para a compreensão da

9 Segundo Taine (1986, p. 152), "Sieyès tem o mais profundo desprezo pela história". 
crítica do autor de $A$ democracia na América à solução revolucionária francesa. Enquanto seus conterrâneos optaram por uma solução de ruptura que os levou a atropelar hábitos e costumes ancestrais, no caso inglês processou-se uma lenta, porém segura combinação entre os valores aristocráticos e o emergente estado social igualitário, possibilitando que o desenvolvimento gradual dos costumes democráticos não comprometesse a liberdade (TOCQUEVILLE, 1987, p. 62).

Ernest Renan reforça essa perspectiva durante o traumático ano de 1871. Para ele, a Inglaterra corresponde ao tipo mais perfeito da marcha regular dos Estados saídos da feudalidade. Ao contrário da França, que eliminou a importância de sua nobreza rural, destruindo a vida provincial, "[...] a Inglaterra, sem romper com sua realeza, com seus condados, com suas comunas, com sua Igreja, com suas universidades, achou meio de ser o Estado mais livre, o mais próspero e o mais patriota que existe" (RENAN, 1872, p. 5).

Similar interpretação está presente em diversos momentos da obra de Le Bon. Em seu Psicologia das Multidóes (1895), ele alega que preservar as instituiçóes do passado constitui o grande desafio dos povos, entretanto apenas os ingleses têm sido contemporaneamente bem-sucedidos nessa tarefa (LE BON, 2008). Em um de seus últimos livros, reitera a convicção segundo a qual são os insulares o povo que mais fortemente conserva suas tradiçóes, percebendo e aceitando o fato de que "as vontades dos mortos orientam imperiosamente as açóes dos vivos" (LE BON, 1927, p. 128).

$\mathrm{O}$ argumento pode ser encontrado, em 1902, sob a pena de Vilfredo Pareto. Assim como Le Bon, ele reflete sobre a contemporaneidade sob o signo do horror que lhe inspira a ascensáo das massas à cena política - sintoma de decadência intelectual europeia da qual apenas a Inglaterra escaparia, pois “[...] a Common Law, pelo fato de repousar na tradiçáo, é uma garantia preciosa contra o despotismo de uma maioria política” (PARETO, 1984, p. 144). Reencontra-se aqui, sob léxico diverso, o elogio tocquevilliano à solução transformista inglesa: a elite local teria tido a sagacidade de ceder posiçóes quando ainda lhe era possível salvaguardar algumas delas, de modo que, entre os insulares, "a circulação de elites não se interrompeu, e a antiga elite soube dar lugar à nova” (PARETO, 1984, p. 152). 
À ambição de que a Inglaterra, na qualidade de espécie de bastião do método da continuidade ${ }^{10}$, cumpra o papel de "nurse da Europa" (ORTEGA Y GASSET, 2007, p. 35), subjaz a convicção conservadora segundo a qual os valores inversamente proporcionais da liberdade e da igualdade coexistiriam harmonicamente além-Mancha - eis a chave da excepcionalidade inglesa.

Em sua extensa maioria, entretanto, os exemplos históricos parecem reiterar a incompatibilidade entre os contraditórios objetivos da igualdade e da liberdade (COMPAGNON, 2011; NISBET, 1987). Em reação aos primeiros, o conservadorismo recupera, do pensamento feudal, a ideia qualitativa de liberdade, compreendendo-a como "[...] a habilidade de cada homem para se desenvolver, [...] conforme a lei e o princípio de sua própria personalidade" (MANNHEIM, 1982, p. 121). Dada, porém, a "inabalável rocha das desigualdades naturais" (LE BON, 1910, p. 11), "[...] todos os esforços para compensar esta diversidade de forças por meio da lei e do governo só podem prejudicar as liberdades [...]; especialmente [...] dos mais fortes e mais brilhantes" (NISBET, 1987, p. 84).

Burke (1997, p. 81), ao assegurar, em suas Reflexóes, que "os niveladores [...] apenas mudam e pervertem a ordem natural das coisas", anuncia sua certeza quanto às divergências constitutivas entre os valores da igualdade $\mathrm{e}$ da liberdade. Este antagonismo pode ser justificado historicamente, como o faz Renan (1972); mas, na virada do século XIX para o XX, certas teorias científicas do social transferem a explicação para aquela incomensurabilidade ao âmbito da natureza, fundado na força e na desigualdade. Trata-se da atribuição de estatuto científico às forças irracionais que governam o comportamento humano (HIRSCHMAN, 1997); em outros termos, da tentativa de naturalização dos preconceitos.

Se o conservadorismo denuncia os limites da razáo iluminista, manifestos na débil crença na racionalidade da ação humana é, mais uma vez, pela recusa ao universalismo, identificado permanentemente com a igualdade. Para Burke, os homens não atuam guiados pelo cálculo racional, mas orientados

10 Ao método da continuidade (ou da "razão histórica"), Ortega y Gasset opõe o "método revolucionário", cuja origem se localiza na França de meados do século XVIII. Trata-se de procedimento condenado ao malogro: "Nas revoluções, a abstração tenta sublevar-se contra o concreto; por isso, as revoluções e o fracasso são consubstanciais" (ORTEGA Y GASSET, 2007, p. 31). 
pelos hábitos e costumes sedimentados pela tradição. É a pregnância histórica que confere densidade a um preconceito.

Ao reduzir a argumentaçáo racional a formas de verniz lógico que os homens formulam para justificar suas majoritárias açóes não lógicas (ARON, 1987), Pareto ilustra o modo por meio do qual são racionalizados hábitos e costumes. Mas, para o Marquês de Parigi, a recorrência histórica náo se esgota em si mesma. Sem abrir mão do relativismo (Pareto, 1984), ele identifica na divisáo das sociedades em elites e massas a constante que, a despeito das suas específicas manifestaçóes históricas, estabelece um princípio absoluto em uma corrente de pensamento que sempre se afirmou circunstanciada (PARETO, 1984). No universo paretiano, o preconceito recorrente adquire status de lei social. Por isso, em seu Curso de Economia Política (1897) não é a história que explica o necessário fracasso dos sistemas socialistas, pois "[...] a desigualdade da distribuição das rendas parece depender [...] muito mais da natureza dos homens do que da organização econômica da sociedade" (PARETO, 1984 apud ARON, 1997, p. 427, grifos meus).

Por volta da mesma época, Le Bon chega a conclusóes semelhantes; porém, para ele, a compreensáo dos mecanismos irracionais que orientam a vida social exige o conhecimento das leis psicológicas próprias às diversas raças humanas ${ }^{11}$. As determinaçóes étnicas, que justificam a fragmentação das sociedades em minorias e maiorias, revelam a incompatibilidade entre as reivindicações democráticas e as desigualdades naturais, denunciando a ilusão subjacente às tentativas de "estabelecer artificialmente a igualação recusada pela natureza” (LE BON, 1922, p. 287).

Atribuir aos atavismos raciais o apego de certos grupamentos humanos às quimeras igualitárias permite a Le Bon construir a grande dualidade sobre a qual se ergue sua filosofia da história: a oposição entre latinos e anglo-saxóes ${ }^{12}$.

II Se Pareto atribui pouca importância às explicações raciais, não se pode dizer que as refute absolutamente: "Em lugar de reduzir todos os fenômenos sociais às condições econômicas, há autores que gostariam de fazê-los depender unicamente da raça. Se chegam a definir isso rigorosamente, o que não é fácil, encontram-se num terreno mais sólido que aquele onde estão os partidários da interpretação vulgar do materialismo histórico, pois a raça é coisa que pode, até certo ponto, ter uma existência independente dos fenômenos sociais que se trata de explicar" (PARETO, 1984, p. 131).

12 Abundam, em seus liuros, referências às distinções entre latinos e anglo-saxões. Psychologie Du Socialisme ( I898) é, provavelmente, aquele no qual elas são mais numerosas. Ver especialmente o Liuro III (LE BON, I984. p. 88-173). 
Trata-se de releitura particular daquele contraste, caro ao pensamento conservador, entre a igualdade francesa e a liberdade inglesa. Sob sua pena, entretanto, ilustra-se de forma especialmente evidente como o elogio aos insulares confunde-se com o apreço pela livre concorrência e, por derivação, como à censura aos franceses está implícita suposta predileção nacional pelo intervencionismo estatal.

Se forçoso fosse definir-se por uma palavra a diferença entre a Europa continental e os Estados Unidos, poderíamos dizer que a primeira representa o máximo que pode dar a regulamentação oficial substituindo a iniciativa individual, os segundos, o máximo que pode dar a iniciativa individual absolutamente desembaraçada de qualquer regulamentação oficial. Estas diferenças fundamentais são exclusivamente consequência do caráter. (LE BON, 2008, p. 124).

A primeira geração conservadora vai de encontro a postulados fundamentais do pensamento liberal, alguns sobre os quais se falou mais acima, tais como a defesa dos direitos naturais e a adesão a uma concepção histórica progressista. Não há discordância significativa, entretanto, quanto à face econômica da agenda liberal. Ambos, conservadores e liberais, prezam pela soberania do laissez-faire.

Há diferenças, evidentemente, no que se refere à concepção de propriedade. No âmbito do conflito revolucionário, o novo regime, ao individualizar o direito de propriedade, torna-se culpado pela destruiçáo dos laços entre o direito de propriedade e as organizaçóes corporativas. Mas, se parte expressiva do conservadorismo de fins do século XVIII apega-se ainda ao conceito feudal de propriedade (MANNHEIM, 1982), perversão mais grave do que a vitória da propriedade privada parece ser sua submissáo ao poder público. Nesse sentido, as divergências entre conservadores e liberais sucumbem em face do inimigo comum: "[...] o Estado moderno [que] cria indistintamente a centralização [...], que caminha de mãos dadas com a democratização inevitável da sociedade" (MAYER, 1952, p. 7).

O repúdio à expansão das atribuições estatais relaciona-se ao elogio à ordem medieval. A ferrenha defesa que faz Burke da assistência privada deriva da perspectiva feudal da interdependência humana. Seu favoritismo pelo setor privado baseia-se na convicção segundo a qual "existem grupos [...] que estão devidamente constituídos para prestar assistência na forma de auxílio-mútuo, 
e não como caridade de altos voos proveniente de uma burocracia" (NISBET, 1987 , p. 105-106).

Sob circunstâncias específicas (NISBET, 1987; STERNHELL, 2010); porém, o Estado pode náo ser o pior dos males. Ele o é quando cumpre seu histórico papel de nivelador, mas pode, excepcionalmente, converter-se no seu contrário. É o que espera Le Bon (1927, p. 292) quando reconhece no fascismo possível alternativa "a governos coletivos impotentes". Mesmo neste caso, todavia, a expectativa é a de que o esvaziamento dos valores intelectuais e morais próprios ao liberalismo coincida com a preservação de sua perspectiva econômica (STERNHELL, 2010). Isto porque, "[d]o ponto de vista estritamente econômico, todo atentado à livre concorrência é um mal" (PARETO, 1984, p. 158). Ou seja, o pensamento conservador associa a ampliação da esfera de ação do poder público a tentativas equivocadas de constranger, por meio de leis sociais, as desigualdades naturais (LE BON, 1910, 2008) e/ou a espontaneidade histórica (ORTEGA Y GASSET, 2007).

Nesse movimento, o Estado, como foi mencionado anteriormente, compromete a pluralidade social, substituindo a contingência pela padronização, isto é, a miríade de possibilidades, inscrita na lógica dos costumes, pela regularidade derivada das abstraçóes. A crítica à potência estatal deriva, enfim, da adesão conservadora ao relativismo, consequência lógica daquele apelo à concretude que se deseja dique ao universalismo progressista.

Trata-se, entretanto, de certo pluralismo preferencialmente limitado ao espaço de experiência. Burke, por exemplo, recusa-se a condenar qualquer forma de governo em abstrato, mas se reconhece que "pode haver casos em que uma democracia pura seja um governo necessário", é para em seguida afirmar que "até o presente, não tivemos exemplos de democracias dignas de nota” (BURKE, 1997, p. 135).

A multiplicidade de costumes opera no interior de um universo se náo circunscrito, ao menos informado diretamente pelo passado. A diferença parece sutil, mas é relevante: na qualidade de filho bastardo da modernidade, o pensamento conservador não nega a necessidade de inovaçóes, desde que lentas e graduais. Seu alvo não são quaisquer mudanças, mas aquelas que se processam velozmente, atropelando hábitos e costumes cristalizados nas tradiçóes. A prescrição de Maistre (2010), segundo a qual é preciso inovar 
com moderação e receio, encontra sagaz tradução nas palavras de Mannheim (1982, p. 117-118):

O reformismo conservador consiste na substituição de fatores individuais por outros fatores individuais ("melhoramentos"). O reformismo progressista tende afastar um fato indesejável através da reforma de todo o mundo circundante que torna possível sua existência. Assim, o reformismo progressista tende considerar o sistema como um todo, enquanto o reformismo conservador considera detalhes particulares.

Para o conservador, portanto, o problema é menos a mudança do que o escopo e o ritmo que ela pode adquirir. Se, conforme sugeri, não se trata de defender a imutabilidade das instituiçóes sociais, a boa transformação é aquela orientada pelas regras da prudência. A ciência do governo, assinala Burke (1997, p. 91), demanda mais experiência "do que aquela que um indivíduo pode adquirir durante a vida”. A embasar tal convicção, o reconhecimento da imperfeiçáo humana, derradeira característica do pensamento conservador foi aqui analisada.

Em reação ao conceito iluminista de progresso, os partidários do conservadorismo denunciam a incapacidade dos homens tanto de abarcar a complexidade dos fenômenos sociais quanto de dirigi-la rumo à perfeiçáo. A arrogância, cara aos racionalistas, não lhes permitia, por um lado, reconhecer a miopia das concepções teleológicas, próprias às modernas filosofias da história, em relação às consequências não previstas da ação (COUTINHO, 2014; MERTON, 1976). Por outro lado, a adesão à lei do progresso conduzia, paradoxalmente, ao imobilismo. Em outros termos, o resultado náo previsto do otimismo progressista seria a incitação à preguiça: "Se o progresso [...] é uma fatalidade determinada, a história se faz sozinha, para o homem, mas sem os homens. É por isso que a crença no progresso desmoraliza a história” (COMPAGNON, 2011, p. 65).

Em substituição à vaidade ingênua do panglossianismo racionalista e sua adesão ao conhecimento técnico, os conservadores clamam pela humildade ponderada que emana do conhecimento prático. "O humano escapa à razão físico-matemática como água por uma peneira”, afirma Ortega y Gasset (1982, p. 36), justificando a valorização daquela razão histórica que se revela na concretude dos usos e costumes, ou seja, na tradição. 
Por isso, sob o ponto de vista conservador, a crítica aos ideais progressistas não se traveste de mero pessimismo resignado. Reconhecer as limitaçóes do intelecto humano compóe parte fundamental de uma corrente de pensamento que se autoproclama realista, ao mesmo tempo em que justifica sua adesão a agendas reformistas e seu consequente repúdio a plataformas revolucionárias.

\section{Considerações finais}

As páginas precedentes destacaram certos aspectos gerais que compóem a ideologia conservadora. Em um esforço de síntese, é possível reuni-los em torno de uma construção ideal típica por meio da qual ela adquire sentido específico, não obstante seu frequente uso pouco criterioso no presente.

Assim, é possível afirmar que o conceito de conservadorismo, moderno em seu nascedouro, surge em reaçáo ao impacto provocado pela Revolução Francesa. Este evento marca uma ruptura na forma de percepção do tempo histórico: passado e futuro deixam de coincidir, convertendo em experiência cotidiana aquele divórcio entre espaço de experiência e horizonte de expectativas que o racionalismo progressista possibilitara no âmbito conceitual (KOSELLECK, 2006). Se, a partir de então, a história perde seu caráter exemplar e o futuro rende-se ao desconhecido, a filosofia conservadora dedicar-se-á à denúncia dos elos inextrincáveis entre o passado, o presente e o porvir. Nessa perspectiva, os acontecimentos pregressos mantêm seu caráter pedagógico.

É do passado, igualmente, que vem a inspiração para a crítica ao mundo pós-revolucionário. A valorizaçáo nostálgica da Idade Média relaciona-se menos a ambiçóes restauradoras do que à valorizaçáo das estruturas intermediárias de poder. Se, como enfatiza Tocqueville, o espectro do despotismo democrático (TOCQUEVILLE, 2000) e seu par lógico, a tirania da maioria (TOCQUEVILLE, 1998), rondam o estado social de igualdade, a solução para a constante ameaça passa, para ele, pela necessária reatualizaçáo, em bases irreversivelmente democráticas, dos antigos corpos secundários aristocráticos. Trata-se do apelo à promoçáo de instrumentos que garantam o pluralismo societário ou, em outros termos, os hábitos e costumes das minorias desejosas de subtraírem-se à regra do maior número.

A defesa das instituiçóes intermediárias deriva da certeza quanto à incompatibilidade histórica entre os ideais da igualdade e da liberdade. 
O racionalismo moderno volta suas fichas para a expansão dos primeiros; os conservadores reagem elaborando certa concepçáo de liberdade atrelada à defesa dos preconceitos historicamente sedimentados e, por isso, chancelados pela tradição. Para ilustrar a possibilidade de coexistência entre a agenda igualitária e a manutenção da liberdade, o pensamento conservador dobra-se às virtudes conciliatórias da nação que, dentro de limites, manteve-se imune às convulsóes revolucionárias e, portanto, às mudanças radicais: a Inglaterra.

À apologia à experiência inglesa subjaz a defesa de soluçôes políticas circunstanciadas. Ao invés do apelo às abstraçóes racionais, o apego a mudanças específicas, lentas e graduais que se processam em diálogo com o conhecimento sedimentado pelo tempo. Náo se trata, contudo, de valorizaçáo unilateral do passado. Não só porque, conforme já visto, as transformações são, sim, necessárias, mas também pela forma singular por meio da qual a perspectiva conservadora se relaciona com presente.

Se o conservadorismo é uma ideologia reativa (COUTINHO, 2014), que tende a emergir quando confrontada a propostas radicais de mudança social, é porque seus representantes possuem especial apreço pelo presente. Ainda que esta estima não impeça críticas pontuais à determinada situação vigente, eles manifestam, de modo geral, "propensão a usar e gozar aquilo que está disponível, mais do que a desejar ou procurar outra coisa" (OAKESHOTT, 1999, p. 21). Ser conservador envolve, portanto, grau considerável de satisfaçáo em relação à determinada ordem social. Neste apreço, reside a convicçáo de que seus fundamentos merecem ser preservados, pois encerram elementos positivos que não devem ser ameaçados por expectativas abstratas. Trata-se, em suma, de certa inversão da máxima gramsciana: otimismo da razão [histórica] e pessimismo da vontade.

\section{Referências}

ARON, R. As etapas do pensamento sociológico. Brasília: Ed. Universidade de Brasília, 1997.

BOBBIO, N.; MATTEUCCI, N.; PASQUINO, G.. Conservadorismo. In:

Dicionário de Política. Brasília: Ed. Universidade de Brasília, 1991. p. 242-245.

BURKE, E. Reflexóes sobre a Revolução em França. Brasília: Ed. Universidade de Brasília, 1997. 
CONSTANT, B. De la force Du governement actuel de la France et de la nécessité de s'y rallyer/Des réactions politiques des effets de La Terreur. Paris: Flammarion, 1988.

COMPAGNON, A. Os antimodernos: de Joseph de Maistre a Roland Barthes. Belo Horizonte: UFMG, 2011.

COUTINHO, J. P. As ideias conservadoras explicadas a revolucionários e reacionários. São Paulo: Três Estrelas, 2014.

ELIAS, N. A Sociedade de Corte: investigação sobre a sociologia da realeza e da aristocracia de corte. Rio de Janeiro: Jorge Zahar, 2001.

GAHYVA, H. De Boulainvilliers a Tocqueville: da liberdade como defesa de privilégios à liberdade como defesa de diferenças. Sociologias, Porto Alegre, ano 14, n. 31, p. 168-190, set./dez. 2012.

HIRSCHMAN, A. O pensamento conservador: perversidade, futilidade e risco. Viseu: DIFEL, 1997.

JASMIN, M. Alexis de Tocqueville: a historiografia como ciência da política. Rio de Janeiro: Access, 1997.

KOSELLECK, R. Futuro Passado: contribuição à semântica dos tempos históricos. Rio de Janeiro: Contraponto, 2006.

LE BON, G. Leis psychologicas da evoluçáo dos povos. Lisboa: Tipografia de Francisco Luiz Gonçalves, 1910.

. L'évolution actuelle du monde. Paris: Flammarion, 1927.

A revoluçáo franceza e a psychologia das revoluçóes. Rio de Janeiro: Garnier, 1922.

Psychologiedu Socialisme. Paris: Les Amis de Gustave Le Bon, 1984.

Psicologia das multidóes. São Paulo: Martins Fontes, 2008.

MAISTRE, J. Consideraçóes sobre a França. Coimbra: Ediçóes Almedina, 2010.

MANNHEIM, K. O significado do conservantismo. In: FORACCHI, M. (Org.). Karl Mannheim: Sociologia. São Paulo: Ática, 1982. p. 107-136.

A mentalidade utópica. In: Ideologia e utopia. Rio de Janeiro: Zahar,

[s. d.]. p. 216-285.

MAYER, J.-P. Avertissement. In: TOCQUEVILLE, A. de. Euvres complètes: L'Ancien Régime et la Révolution (Tomo II). Paris: Gallimard, 1952. 
MERTON, R. K. The unanticipated consequences of social action. In: Sociological ambivalence and other essays. Nova Iorque: Free Press, 1976. p. 145-155.

NISBET, R. O Conservadorismo. Lisboa: Estampa, 1987.

OAKESHOTT, M. [1962]. "Do fato de ser conservador". In: CRESPIGNY, A. \& CRONIN, J. Ideologias Políticas. Brasília: UNB, 1999, pp. 21-42.

ORTEGA Y GASSET, J. A rebelião das massas. São Paulo: Martins Fontes, 2007.

História como Sistema/Mirabeau ou o político. Brasília: Ed. Universidade de Brasília, 1982.

PARETO, V. Os sistemas socialistas. In: RODRIGUES, J. (Org.). Pareto: Sociologia. São Paulo: Ática, 1984. p. 112-164.

RENAN, E. La réforme intellectuelle et morale. In: La réforme intellectuelle et morale. Paris: Michel Lévy Frères Ed., 1872. p. 1-121

SIEYÈS, E. A constituinte burguesa: que é o Terceiro Estado? Rio de Janeiro: Liber Júris, 1988.

STERNHELL, Z. Les anti-Lumières: une tradition du XVIII e siècle à la guerre froid. Paris: Gallimard, 2010.

TAINE, H. Les origines de la France contemporaine: l'Ancien Régime. La Révolution: l'anarchie - la conquête jacobine. Paris: Robert Laffont, 1986.

TOCQUEVILLE, A. A democracia na América: sentimentos e opiniōes. São Paulo: Martins Fontes, 2000.

A democracia na América: leis e costumes. São Paulo: Martins Fontes, 1998.

Lembranças de 1848: as Jornadas Revolucionárias em Paris. São Paulo: Cia. das Letras, 1991.

O Antigo Regime e a Revoluçáo. Brasília: Ed. Universidade de Brasília, 1987.

VIANNA, L. W. O problema do americanismo em Tocqueville. In: A revoluçáo passiva: iberismo e americanismo no Brasil. Rio de Janeiro: Revan, 1997. p. 161-193.

WEBER, M. A objetividade do conhecimento nas Ciências Sociais. In: COHN, G. (Org.). Weber: Sociologia. São Paulo: Ática, 1989. p. 79-127. 


\section{Notes on Conservatism: elements for the definition of a concept}

\section{Abstract}

This article is inspired by the imprecise use of the concept of conservatism in contemporary times. What characteristics, after all, define membership in this stream of thought? To answer this question, a typical ideal vision of conservative philosophy it is build by which it is possible to highlight its main premises. To this effect, we focused on the analysis of the concept in motion, that is, in dialogue with some of its most outstanding players.

Keywords: Conservative thought. French Revolution. Equality. Liberty. Social change.

Recebido em: 22/09/2016 Aceito em: 31/01/2017 